\title{
Foraging effort of juvenile Steller sea lions Eumetopias jubatus with respect to heterogeneity of sea surface temperature
}

\author{
Michelle E. Lander ${ }^{1,2, *}$, Thomas R. Loughlin ${ }^{1}$, Miles G. Logsdon ${ }^{3}$, \\ Glenn R. VanBlaricom ${ }^{2}$, Brian S. Fadely ${ }^{1}$ \\ ${ }^{1}$ National Marine Mammal Laboratory, NMFS, 7600 Sand Point Way N.E., Seattle, Washington 98115, USA \\ ${ }^{2}$ Washington Cooperative Fish and Wildlife Research Unit, School of Aquatic and Fishery Sciences, Box 355020, \\ University of Washington, Seattle, Washington 98195, USA \\ ${ }^{3}$ School of Oceanography, Box 357940, University of Washington, Seattle, Washington 98195, USA
}

\begin{abstract}
Among many other factors, the decline of the western distinct population segment of Steller sea lions Eumetopias jubatus in Alaska (USA) has been attributed to changes in the distribution or abundance of prey due to the cumulative effects of fisheries and large-scale climate change. However, the depletion of localized prey resources due to small-scale environmental variability and perturbations may be impeding recovery, resulting in the need to understand how the environment currently affects this species on smaller spatial and temporal scales. The objective of this study, therefore, was to assess how Steller sea lions respond to changes in localized environmental features. Satellite-relayed data loggers were deployed on juvenile Steller sea lions ( $\mathrm{n}=24$ ) from July 2002 to May 2004 in the Aleutian Islands and Gulf of Alaska. Weekly indices of foraging effort (mean and maximum trip duration, diving activity) of Steller sea lions were examined with respect to corresponding patterns of sea surface temperature (SST) data obtained from the moderate resolution imaging spectroradiometer. An assortment of landscape metrics was used to characterize the heterogeneity of frontal features derived from SST gradients because it has been suggested that Steller sea lions depend on prey patches associated with these features. Multivariate analyses indicated that fractal dimension and patch density of frontal features were significant factors for predicting different aspects of foraging effort ( $p<0.05 ; n=6$ models). Overall, results suggested that aggregated frontal features associated with small-scale temperature gradients were probably conducive to foraging effort of Steller sea lions, but additional mechanisms should be investigated further.
\end{abstract}

KEY WORDS: Eumetopias jubatus · Environmental heterogeneity · Foraging effort · Fractal dimension $\cdot$ Frontal features $\cdot$ Gradients $\cdot$ Sea surface temperature $\cdot$ Steller sea lion

\section{INTRODUCTION}

Over the past $30 \mathrm{yr}$, populations of Steller sea lions Eumetopias jubatus in western Alaska (USA) have declined by $80 \%$ (Braham et al. 1980, Loughlin 1998, Fritz et al. 2008). Decreased juvenile survival and reproductive rates have been implicated as proximate factors for the decline of the endangered, western distinct population segment (wDPS) of Steller sea lions
(York 1994, Merrick 1995, York et al. 1996, Holmes \& York 2003, Holmes et al. 2007). Nutritional stress resulting from changes in distribution, abundance, or quality of prey due to commercial fisheries and largescale oceanographic changes is among the ultimate factors proposed for explaining the decline (Merrick 1995, Loughlin 1998, Loughlin \& York 2000, DeMaster \& Atkinson 2002). Short-term environmental variability and local environmental perturbations have also 
been suggested as hypotheses for population decline (Pascual \& Adkinson 1994, Merrick 1995, Benson \& Trites 2002) or lack of recovery (Fritz \& Hinckley 2005, Atkinson et al. 2008, NMFS 2008), resulting in the need to understand how the environment currently affects Steller sea lions at finer scales in local coastal areas (Trites et al. 2007).

Steller sea lions heavily utilize nearshore habitats (Merrick \& Loughlin 1997, Loughlin et al. 2003, RaumSuryan et al. 2004) by adopting a strategy of central place and multiple central place foraging to cope with the spatial and temporal distribution of localized prey resources (Raum-Suryan et al. 2004). Although the foraging behavior of juvenile Steller sea lions has been fairly well detailed (Merrick \& Loughlin 1997, Loughlin et al. 2003, Raum-Suryan et al. 2004, Fadely et al. 2005, Pitcher et al. 2005, Call et al. 2007), few studies have assessed the effects of environmental features on foraging effort. Loughlin et al. (2003) satellite-tagged 25 juvenile Steller sea lions from 1994 to 2000 in Alaska and Washington and concluded that Steller sea lions have the foraging flexibility to take advantage of predictable behavioral traits of prey species and localized oceanographic conditions that enhance prey concentrations. Others have suggested that Steller sea lions are constrained by prey persistence (Gende \& Sigler 2006) and changes in prey availability resulting from seasonal variability (Merrick \& Loughlin 1997, Womble \& Sigler 2006), and that they depend on the presence of large, dense prey patches associated with nearshore temperature gradients (Sinclair \& Zeppelin 2002). Hence, further analyses of telemetry data are needed to understand relationships of foraging behaviors with environmental variability and spatial patterns of oceanographic structure, which ultimately affect the distribution or abundance of prey (Loughlin et al. 2003). For example, the oceanographic structure of water temperature likely influences prey distribution, which in turn affects foraging behavior and possibly fecundity or mortality of Steller sea lions (Pascual \& Adkinson 1994).

Spatial and temporal heterogeneity of the environment have been empirically and conceptually challenging to ecologists because complex environments are difficult to describe quantitatively. Furthermore, ecologists have become increasingly aware of the importance of examining ecological processes at scales relevant to the organism and process under study (Turner et al. 1989, Wiens 1989). This is especially important in the marine environment, which is a highly dynamic system. However, with advances in geographic information systems (GIS) and remote sensing techniques, the spatial heterogeneity of the marine environment can be characterized over time by an assortment of patches and gradients (White \& Brown
2003), which are considered the structural and functional components of landscapes (Cadenasso et al. 2003). Spatial patterns of ocean structure and heterogeneity can be quantified through time using an assortment of landscape metrics, which focus on the abundance (i.e. composition) and spatial arrangement or complexity (i.e. configuration) of patches (Gustafson 1998, McGarigal et al. 2002). The quantification of environmental heterogeneity using these metrics has become a common practice in the advancing field of landscape ecology, which is the study of landscape patterns, ecological processes that influence patterns, and effects of patterns on population persistence and animal movement (Hargis et al. 1997, Fahrig \& Nuttle 2003, Lovett et al. 2003). Although landscape ecology has traditionally focused on ecological processes and spatial patterns in terrestrial ecosystems, the principles of this discipline can also be applied to aquatic systems (Wiens 2002).

If environmental heterogeneity is in part responsible for changing the abundance or distribution of prey for Steller sea lions on a localized scale, then changes in environmental features should be reflected in patterns of sea lion foraging behavior. The objective of this study, therefore, was to assess how Steller sea lions respond to changes in heterogeneity of the environment at spatial scales relevant to individual sea lion perception. More specifically, the foraging effort of Steller sea lions was examined with respect to an assortment of landscape metrics that were used to characterize spatial patterns of sea surface temperature (SST) gradients. We chose to work with SST as an environmental indicator because it has been hypothesized to affect Steller sea lions on multiple scales (Sinclair \& Zeppelin 2002, Trites et al. 2007) and has been linked to food habits and population dynamics at regional scales (Call \& Loughlin 2005, Lander et al. 2009). Additionally, SST allows for differentiating water mass structure (Boyd et al. 2001) and can be used to derive oceanographic frontal features, which we elaborate on in the methods.

\section{MATERIALS AND METHODS}

Juvenile Steller sea lions were opportunistically captured at rookeries or haulout sites within the Gulf of Alaska and Aleutian Islands using hoop nets or dive captures (McAllister et al. 2001; Table 1, Fig. 1). Animals were either sedated with valium (1.1 to $2.0 \mathrm{ml}$ ) and manually restrained or anesthetized (Heath et al. 1997). Sea lions were weighed to the nearest $0.5 \mathrm{~kg}$, and standard length and axial girth were measured to the nearest $1.0 \mathrm{~cm}$. Measurements of tooth size (upper canine), body size, and time of 
Table 1. Eumetopias jubatus. Capture location, including latitude, longitude (decimal degrees), region, and date of capture, date of last transmission for satellite transmitters, number of days tracked, sex, age at capture, and study area for juvenile Steller sea lions, as indicated by their identification (ID) number. WAI: western Aleutian Islands, CGA: central Gulf of Alaska, EAI: eastern Aleutian Islands, CAI: central Aleutian Islands, M: male, F: female. Dates given as mo/d/yr. Data for 3 individuals were discarded because of sensor failure (nos. 8245 and 9928) or limited data (no. 9929)

\begin{tabular}{|c|c|c|c|c|c|c|c|c|c|c|}
\hline ID & Location & $\begin{array}{c}\text { Latitude } \\
\left({ }^{\circ} \mathrm{N}\right)\end{array}$ & $\begin{array}{l}\text { Longitude } \\
\qquad\left({ }^{\circ} \mathrm{E}\right)\end{array}$ & Region & $\begin{array}{l}\text { Date of } \\
\text { capture }\end{array}$ & $\begin{array}{l}\text { Date of last } \\
\text { transmission }\end{array}$ & $\begin{array}{l}\text { No. of days } \\
\text { tracked }\end{array}$ & Sex & $\begin{array}{l}\text { Age } \\
(\mathrm{mo})\end{array}$ & $\begin{array}{c}\text { Study } \\
\text { area }\left(\mathrm{km}^{2}\right)\end{array}$ \\
\hline 7820 & Buldir & 52.340 & 175.900 & WAI & 07/03/02 & 08/13/02 & 41 & M & 12 & 35248.2 \\
\hline 7821 & Attu & 52.918 & 172.461 & WAI & 07/05/02 & 08/24/02 & 50 & $\mathrm{~F}$ & 12 & 10834.2 \\
\hline 7822 & Attu & 52.918 & 172.461 & WAI & 07/05/02 & $07 / 20 / 02$ & 15 & F & 12 & 14400.8 \\
\hline 8245 & Long Island & 57.778 & -152.416 & CGA & $02 / 27 / 03$ & 03/06/03 & 7 & F & 9 & - \\
\hline 8250 & Aiktak & 54.183 & -164.852 & EAI & 03/05/03 & 04/19/03 & 45 & F & 21 & 2869.6 \\
\hline 8252 & Aiktak & 54.183 & -164.852 & EAI & 03/07/03 & 03/26/03 & 19 & $\mathrm{~F}$ & 21 & 2452.2 \\
\hline 9922 & Tigalda Rocks & 54.139 & -164.978 & EAI & $11 / 10 / 03$ & $12 / 14 / 03$ & 34 & $\mathrm{~F}$ & 5 & 4130.6 \\
\hline 9923 & Tigalda Rocks & 54.139 & -164.978 & EAI & $11 / 10 / 03$ & $11 / 22 / 03$ & 12 & $\mathrm{~F}$ & 5 & 3744.3 \\
\hline 9924 & Tigalda Rocks & 54.139 & -164.978 & EAI & $11 / 10 / 03$ & 01/03/04 & 54 & $\mathrm{~F}$ & 5 & 1808.4 \\
\hline 9925 & Two Headed Isl. & 56.897 & -153.569 & CGA & $11 / 16 / 03$ & $02 / 12 / 04$ & 88 & $\mathrm{M}$ & 5 & 2869.6 \\
\hline 9926 & Two Headed Isl. & 56.897 & -153.569 & CGA & $11 / 16 / 03$ & $12 / 26 / 03$ & 40 & $\mathrm{~F}$ & 5 & 2452.2 \\
\hline 9927 & Two Headed Isl. & 56.897 & -153.569 & CGA & $11 / 16 / 03$ & $01 / 11 / 04$ & 56 & $\mathrm{M}$ & 17 & 4130.6 \\
\hline 9928 & Two Headed Isl. & 56.897 & -153.569 & CGA & $11 / 16 / 03$ & $12 / 22 / 03$ & 36 & $\mathrm{M}$ & 5 & - \\
\hline 9929 & Two Headed Isl. & 56.897 & -153.569 & CGA & $11 / 16 / 03$ & $11 / 22 / 03$ & 6 & $\mathrm{M}$ & 5 & - \\
\hline $10006^{\mathrm{a}}$ & Two Headed Isl. & 56.897 & -153.569 & CGA & $11 / 17 / 03$ & $01 / 02 / 04$ & 46 & M & 5 & 2154.8 \\
\hline 9930 & Long Island & 57.781 & -152.278 & CGA & 11/18/03 & 05/17/04 & 181 & $\mathrm{~F}$ & 29 & 24891.5 \\
\hline 10007 & Kagalaska & 51.866 & -176.340 & CAI & 05/06/04 & 07/07/04 & 62 & M & 11 & 12260.9 \\
\hline 10008 & Kagalaska & 51.865 & -176.340 & CAI & 05/07/04 & $07 / 20 / 04$ & 74 & $\mathrm{M}$ & 11 & 5492.6 \\
\hline 10009 & Silak Island & 51.865 & -176.340 & CAI & 05/07/04 & $07 / 23 / 04$ & 77 & $\mathrm{M}$ & 11 & 4634.8 \\
\hline 10010 & Silak Island & 51.865 & -176.340 & CAI & 05/07/04 & 07/31/04 & 85 & M & 11 & 154125.8 \\
\hline 10011 & Silak Island & 51.865 & -176.340 & CAI & 05/07/04 & 08/02/04 & 87 & $\mathrm{M}$ & 11 & 9178.5 \\
\hline 10012 & Little Tanaga Isl. & 51.823 & -176.340 & CAI & 05/16/04 & $06 / 22 / 04$ & 37 & $\mathrm{~F}$ & 23 & 7957.7 \\
\hline 10013 & Billingshead & 54.290 & -165.580 & EAI & 05/19/04 & 07/01/04 & 43 & $\mathrm{M}$ & 11 & 32665.1 \\
\hline 10014 & Akun Island & 54.290 & -165.580 & EAI & 05/19/04 & 06/27/04 & 39 & M & 35 & 44530.7 \\
\hline
\end{tabular}

year were used to infer ages of all sea lions (King et al. 2007). Satellite relayed data loggers (SRDLs; Sea Mammal Research Unit [SMRU], Gatty Marine Laboratory, University of St. Andrews, Scotland) were attached to the dorsal pelage of each sea lion using Five Minute Epoxy (Devcon).

In addition to providing location data, the SRDLs were programmed to maintain a 3-state model of animal activity, determined from time interactions and surface and depth sensors. Information on behavior was processed and compressed into records of behavioral states including time spent on shore (i.e. hauled out), extended surface periods, and dive cycles. Sea lions were considered hauled out when on shore (dry) for more than $6 \mathrm{~min}$, whereas surface periods were defined as the time at sea (wet) above a defined dive threshold $(<6 \mathrm{~m})$ for more than $6 \mathrm{~min}$. Dives were defined as being $>6 \mathrm{~m}$ in depth and $>8 \mathrm{~s}$ in duration. Due to bandwidth restrictions, dives were sampled at intervals of $4 \mathrm{~s}$, stored in memory, randomly sampled, and transmitted in bouts of 2 or 7 to ensure they were a representative sample of the time spent at sea (Fedak et al. 2002). Each day, temperature profiles were also collected every $2 \mathrm{~h}$ during the deepest dive.
Haulout, surface, and dive records reported by the SRDLs contained the start and end times of unbroken periods spent in each state of activity. SRDLs also collated summary statistics on the proportion of time spent in each of the 3 states for six $4 \mathrm{~h}$ periods $\mathrm{d}^{-1}$ (period $1=0: 00-3: 59 \mathrm{~h}$, period $2=4: 00-7: 59 \mathrm{~h}$, period $3=8: 00-11: 59 \mathrm{~h}$, period $4=12: 00-15: 59 \mathrm{~h}$, period $5=$ 16:00-19:59 h, period $6=20: 00-23: 59 \mathrm{~h}$ Greenwich Mean Time, GMT). Daily locations and behavioral data from SRDLs were obtained through the Service Argos system (Argos 1996) and decoded in a marine mammal behavior visualization system (MAMVIS; Fedak et al. 1996) by the SMRU. All data were filtered using a swim speed of $2 \mathrm{~m} \mathrm{~s}^{-1}$ with the algorithm described by McConnell et al. (1992), and time was used as a means to interpolate the position of dives along a direct line between successive locations.

Standard mapped images of SST (level 3, weekly composites, $4.6 \mathrm{~km}$ resolution) collected by the moderate resolution imaging spectroradiometer (MODIS) instrument aboard NASA's Aqua satellite were obtained from the Ocean Color Discipline Processing System (Campbell et al. 1995). Windows Image Manager (6.2; Wimsoft) was used to clip a northern sub- 


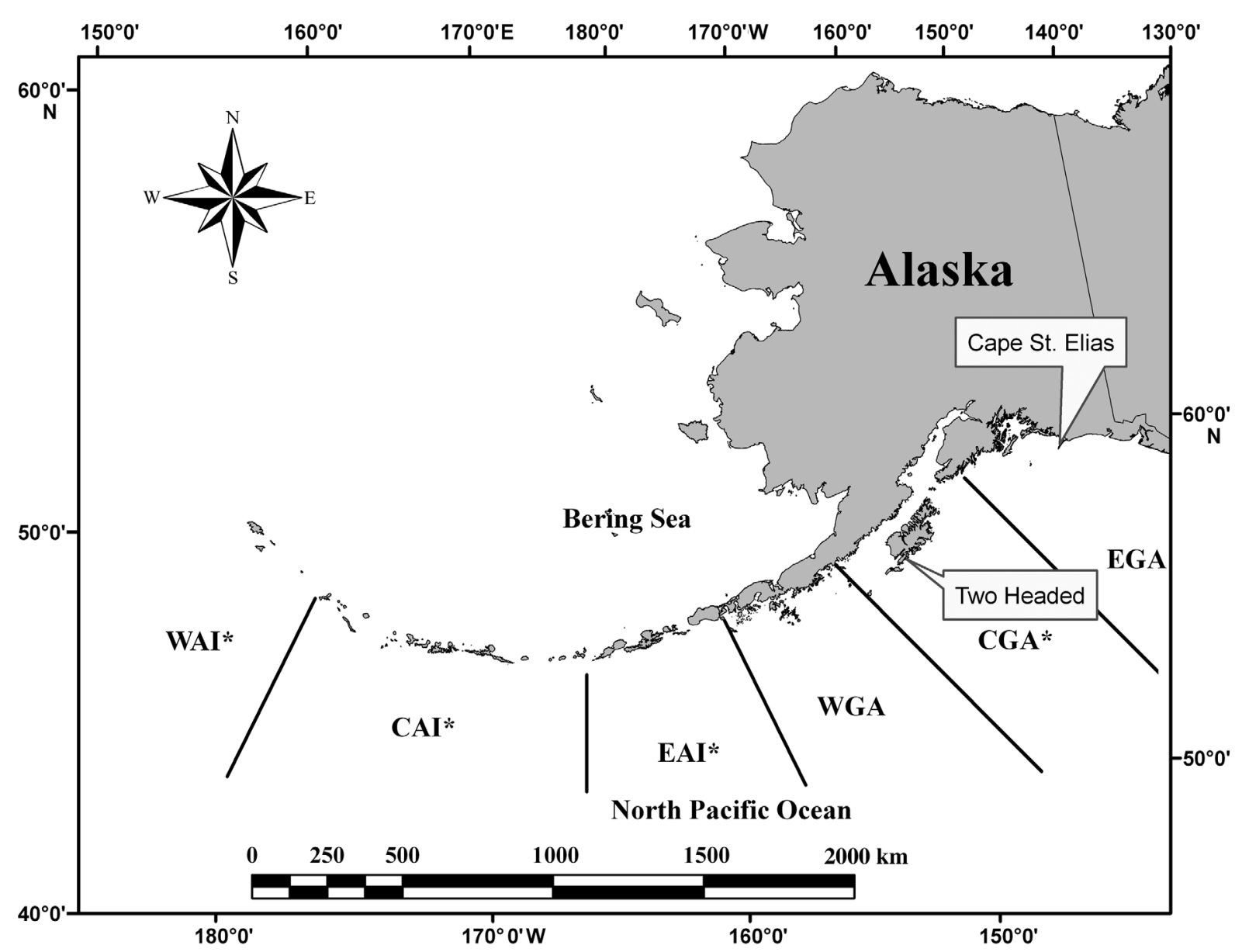

Fig. 1. Eumetopias jubatus. Geographical regions in Alaska comprising the western distinct population segment (wDPS) of Steller sea lions. Asterisks $\left({ }^{*}\right)$ indicate regions where sea lions $(\mathrm{n}=24)$ were captured. Regions include the western Aleutian Islands (WAI), central Aleutian Islands (CAI), Eastern Aleutian Islands (EAI), western Gulf of Alaska (WGA), central Gulf of Alaska (CGA), and eastern Gulf of Alaska (EGA)

polar region (including Alaska) from all global remote sensing images, and ENVI (4.0; ITT Visual Information Solutions) was used to define the datum (i.e. NAD83). ArcInfo was used to convert all remote sensing data to raster grids and project them to an Albers equal-area conic projection defined for the state of Alaska, USA (ArcGIS 9.0, ESRI). SST data for the week of 28 July to 4 August 2002 were not available for analyses.

With the exception of 1 individual (no. 10006), 1 study area was devised for each individual by plotting all data collected for the duration of instrument deployment. A minimum convex polygon (MCP) constituting a simple home range was superimposed on the telemetry data (Hawths Analysis tools extension, ArcGIS) for each individual and buffered by $15 \mathrm{~km}$ to alleviate edge effects and to account for error of satellite telemetry positions, which ranges from 0.4 to $17.4 \mathrm{~km}$ in areas of Alaska (Fadely et al. 2005). Each buffered MCP was then enclosed by a rectangular area that totally covered the geometry of the polygon (Fig. 2). Study areas were deemed the 'area of influence' for each individual assuming these represented individual perception. Weekly SST grids were then clipped to each individual study area. The same methods were used to devise 3 study areas representing habitat use before, during, and after a trip conducted by sea lion no. 10006, a 5 mo old pup that dispersed $\sim 615 \mathrm{~km}$ from Two Headed Island to Cape St. Elias $11 \mathrm{~d}$ after being tagged (Table 1, Fig. 1). The methods were modified for this individual because we assumed it followed its mother on that excursion and the entire Gulf of Alaska was not influencing its foraging effort.

Data classification. To examine environmental heterogeneity for this study, weekly categorical maps comprising SST patches and gradients were derived for categorical map analysis. Frontal features, which are hydrographic features generally defined as an interface between 2 dissimilar water masses and often characterized by a steep temperature gradient (Etnoyer et al. 2006), were defined as cells where the 


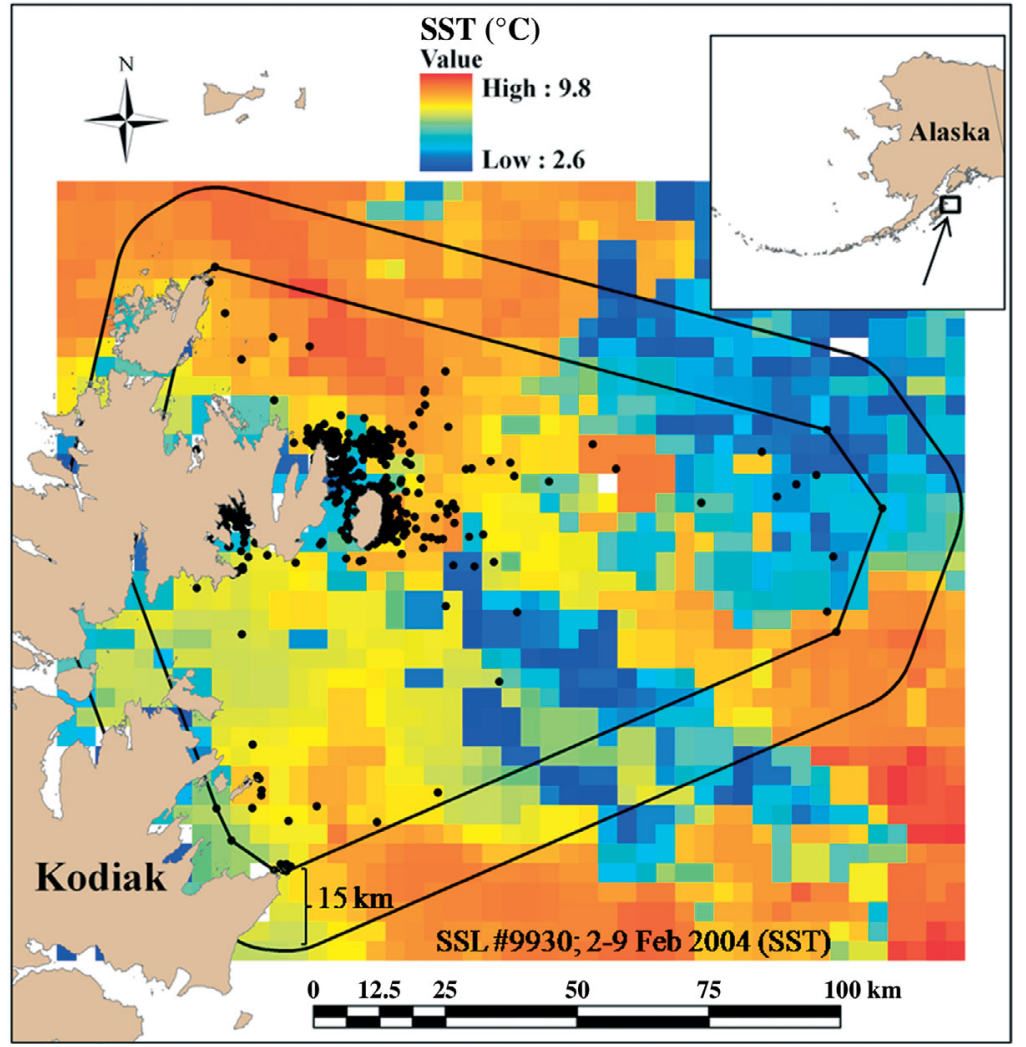

Fig. 2. Eumetopias jubatus. An example illustrating how study areas were devised for 21 juvenile Steller sea lions. A minimum convex polygon was superimposed on pooled, filtered telemetry data for each individual, buffered by $15 \mathrm{~km}$, and then enclosed by a rectangular area that totally covered the geometry of the polygon. Weekly sea surface temperature grids were then clipped to each individual study area
SST gradient was greater or less than $1 \mathrm{SD}$ from the mean gradient of the study area for each individual (Moore et al. 2002); hence, this classification scheme resulted in 3 data classes (Fig. 3). To create gradients, defined as a change in a property across a defined spatial extent representing a pattern of continuous variation of a single focal variable (Lovett et al. 2003, White \& Brown 2003), the slope function (Spatial Analyst extension, ArcGIS 9.1) was used to calculate the rate (degrees) of maximum change in SST from each data cell and its 8 neighbors for each weekly grid per individual.

After data classification, FRAGSTATS 3.3 (McGarigal \& Marks 1995) was used to determine the number of patches corresponding to each data class, where a patch was defined as a contiguous group of cells of the same mapped category using an 8-neighbor rule (i.e. 2 grid cells of the same cover type are considered part of the same patch if they are adjacent or diagonal neighbors; Forman \& Godron 1986, Turner et al. 2001). Three landscape metrics, which measure the aggregate properties of the entire grid mosaic, were used to characterize heterogeneity of SST for each remote sensing week, including patch density (PD), Simpson's diversity index (SIDI), and area-weighted mean
A
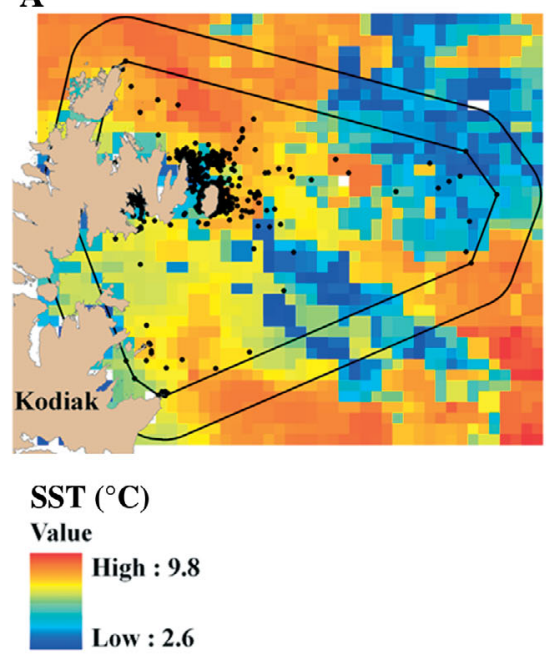

B

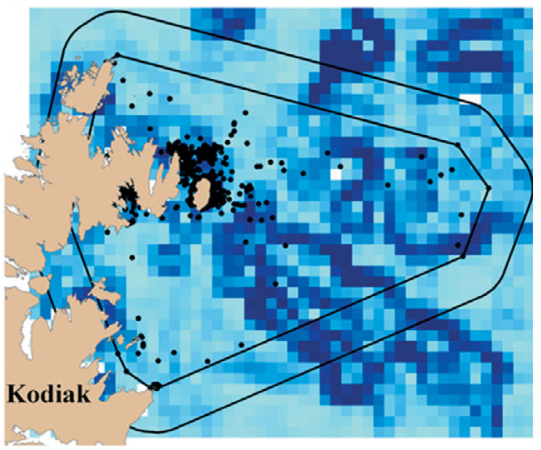

Gradient; inclination of slope $\left({ }^{\circ}\right)$ mean $=0.009136392, \mathrm{SD}=\mathbf{0 . 0 0 8 2 0 7 2 9 9}$

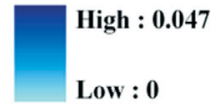

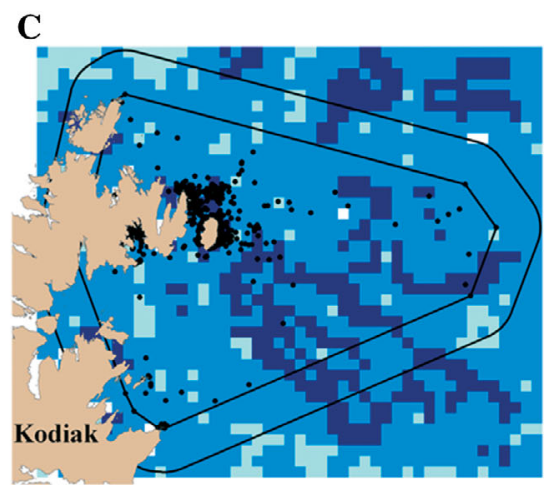

Classified data

Gradient

$0.017343691-0.046683744$ (class 3 ; frontal feature) $0.000929093-0.017343691$ (class 2; mean \pm 1 SD) 0 - 0.000929093 (class 1; frontal feature)

Fig. 3. Eumetopias jubatus. The methodology used for classifying (A) weekly sea surface temperature (SST) data entailed (B) deriving SST gradients by calculating the rate of maximum change in SST from each data cell and its 8 neighbors. (C) Frontal features were then defined as cells where the SST gradient was greater (class 3) or less than (class 1) 1 SD from the mean gradient of the study area for each individual 
fractal dimension (AMFD). We chose to examine PD and SIDI of SST because Lander et al. (2009) found that these covariates may be linked to regional population trends of Steller sea lions, whereas AMFD provides a measure of complexity.

PD (total number of patches area ${ }^{-1}$ ) was computed for individual study areas and reported as number of patches per 100 ha. The AMFD was calculated using the following metric:

$$
\mathrm{AMFD}=\sum_{i=1}^{n}\left\{\left[\frac{2 \ln \left(0.25 p_{i}\right)}{\ln a_{i}}\right]\left(\frac{a_{i}}{\sum_{i=1}^{n} a_{i}}\right)\right\}
$$

where $n=$ total number of patches, $p_{i}=$ perimeter $(\mathrm{m})$ of patch $i$, and $a_{i}=$ area $\left(\mathrm{m}^{2}\right)$ of patch $i$. This metric increases as shape complexity of patches within the landscape mosaic increases and is advantageous because it represents complexity (or departure from Euclidean geometry) across a range of spatial scales (i.e. patches). This metric was weighted because small maps are more prone to effects caused by map borders; a greater proportion of patches are truncated at the edges of the map (Hargis et al. 1997). Additionally, SIDI was calculated for each week using the following metric:

$$
\mathrm{SIDI}=1-\sum_{i=1}^{c} P_{i}^{2}
$$

where $P_{i}=$ the proportion of the landscape occupied by class type $i$, and $c=$ the number of classes present. SIDI represents the probability that any 2 pixels selected at random would be different patch types (McGarigal et al. 2002), and SIDI $=0$ when the area is dominated by 1 patch (no diversity) and approaches 1 as the number of different patch types increases and the proportional distribution of area among patch types becomes more even. Relative to other diversity indices (e.g. Shannon's diversity index), SIDI is less sensitive to the presence of rare patch/group types, so more weight is placed on common patch/group types. This characteristic coupled with a fairly consistent number of map classes (i.e. richness) across regions enabled us to avoid problems associated with having study areas of different sizes.

Four class metrics were computed only for patches corresponding to map classes representing frontal features to further elucidate how these specific patches influenced the foraging effort of sea lions. In addition to PD and AMFD, area-weighted mean class area (AMCA) was calculated using the following metric:

$$
\mathrm{AMCA}=\frac{\sum_{j=1}^{n}\left[a_{i j}\left(\frac{a_{i j}}{\sum_{j=1}^{n} a_{i j}}\right)\right]}{10000}
$$

where $a_{i j}=$ area $\left(\mathrm{m}^{2}\right)$ of patch $\mathrm{ij}$ and $\mathrm{n}=$ number of patches corresponding to frontal features. The metric is divided by 10000 to convert to ha. Additionally, the percentage of landscape (PLAND) comprising these classes was also calculated ( $\Sigma$ area of each designated class patch/area $\times 100$ ). This estimate approaches 100 as the entire image becomes composed of a single patch (McGarigal et al. 2002).

Statistical analysis. Trip durations for individual sea lions were calculated using the departure and arrival times for trips at sea provided in the haulout records. Mean trip duration and percentage of time spent diving for each sea lion were calculated for each remote sensing week. Trips that straddled 2 weeks were assigned to the week containing the greater proportion of the trip. Maximum trip duration $w^{-1}$ was also examined for each individual. All partial weeks were used in analyses.

Mean and maximum trip duration $\mathrm{wk}^{-1}$ were logtransformed after conducting Kolmogorov-Smirnov tests for normality (SPSS 13.0) and examining histograms and $q-q$ plots of the response variables (R 2.4.1, $\mathrm{R}$ Foundation for Statistical Computing). Generalized linear models (GLMs) with a Gaussian error, identity link, and first-order autoregressive correlation structure were used to examine mean and maximum trip duration $\mathrm{wk}^{-1}$, and percentage of time spent diving $\mathrm{wk}^{-1}$ with respect to the covariates region, age (at capture), and environmental metrics described above (geepack 1.0-10, R 2.4.1; Liang \& Zeger 1986, Zeger \& Liang 1986). Individual sea lion was used as the grouping variable. Regions were coded as individual indicator variables, and the central Aleutian Islands (CAI) region was used as the control. These models accounted for longitudinal data, repeated measures, and correlated responses within each sea lion for the response variables, and possible time-dependent covariates. This approach is advantageous because it accounts for serial correlation in the response, is robust to deviations from normality, and employs a quasi-likelihood approach to provide generalized estimating equations (GEE; Yan \& Fine 2004, Halekoh et al. 2006).

Sex was not examined as a predictor variable because preliminary data analyses indicated that the response variables did not differ between males and females. Year or season also were not examined due to paucity of data and because previous studies indicated that year was not an important factor for predicting trip duration for Steller sea lions (Call et al. 2007). Optimal models were developed by using a backward stepwise elimination procedure to remove non-significant terms one at a time based on the significance levels of Wald test statistics ( $p \leq 0.15$ for model retention, $\mathrm{p} \leq 0.05$ for significance). Separate 
analyses were conducted for each response variable for the 2 different groups of metrics (i.e. landscape and class metrics; $\mathrm{n}=6$ models). Lastly, to assess the appropriateness of final models, q-q plots and residual plots were examined (R 2.4.1).

\section{RESULTS}

From 3 July 2002 to 19 May 2004, 24 juvenile Steller sea lions (5 to 35 mo old) were captured at rookeries or haulout sites within the western $(\mathrm{n}=3)$, central $(\mathrm{n}=$ $6)$, and eastern $(\mathrm{n}=7)$ Aleutian Islands, and the central Gulf of Alaska ( $n=8$; Fig. 1, Table 1). Data for 3 individuals were discarded because of sensor failure (nos. 8245 and 9928) or limited data (no. 9929). Instrument deployment for the remaining 21 sea lions lasted from 12 to $181 \mathrm{~d}$. Study areas for individual sea lions ranged from 1808.4 to $154125.8 \mathrm{~km}^{2}$ (Table 1). The 3 study areas representing habitat use before, during, and after the trip conducted by sea lion no. 10006 were $2154.8 \mathrm{~km}^{2}, 216828.9 \mathrm{~km}^{2}$, and $5039.4 \mathrm{~km}^{2}$, respectively.

\section{Trip durations}

Overall, the duration of trips $(n=1475)$ for all individuals $(\mathrm{n}=21)$ ranged from 0.1 to $177.1 \mathrm{~h}$ (mean $\pm \mathrm{SD}$ $=8.6 \pm 14.8 \mathrm{~h}$ ). Average trip duration ind.$^{-1}$ ranged from 3.0 to $28.6 \mathrm{~h}$, whereas maximum trip duration ranged from 14.1 to $177.1 \mathrm{~h}(68.4 \pm 47.8 \mathrm{~h}$; Table 2$)$. Mean trip duration $\mathrm{wk}^{-1}$ ranged from 0.9 to $117.6 \mathrm{~h}$ $\left(12.3 \pm 14.5 \mathrm{~h}, \mathrm{n}=151 \mathrm{wk}\right.$, range $=2-23 \mathrm{wk}$ ind.$\left.^{-1}\right)$.

\section{Activity patterns}

Summary statistics for the 3 behavioral states were obtained for 896 complete records (full $24 \mathrm{~h}$ periods;

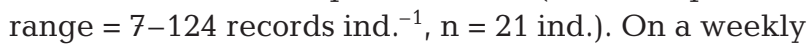
basis, sea lions spent an average \pm SD of $55.7 \pm 18.3 \%$ (range $=0.0-98.3 \%$ ) of their time on shore, whereas $44.3 \pm 18.3 \%$ was spent at sea (range $=1.7-100.0 \%$; $\mathrm{n}=145 \mathrm{wk}$, range $=2-23 \mathrm{wk}$ ind $\left.{ }^{-1}\right)$. While at sea, sea lions spent an average of $11.2 \pm 6.8 \%$ (range $=$ $0.0-28.4 \%$ ) of their time diving and $33.1 \pm 14.2 \%$ (range $=1.5-83.1 \%$ ) of their time at the surface. However, these activities varied considerably within and among individuals (Table 3).

Time of day during which most diving activity occurred varied among individuals, but on average, sea lions spent a greater proportion of time diving at night during period 3 (Table 4), followed by crepuscular periods (periods 2 and 4; Table 4). A greater propor-
Table 2. Eumetopias jubatus. Steller sea lion identification (ID), sample size (number of trips at sea), and mean \pm SD and range (minimum and maximum) of trip duration (h) for individual deployment periods

\begin{tabular}{|c|c|c|c|c|c|}
\hline \multirow[t]{2}{*}{ ID } & \multirow{2}{*}{$\begin{array}{l}\text { No. of } \\
\text { trips }\end{array}$} & \multirow[b]{2}{*}{ Mean } & \multicolumn{2}{|c|}{ Trip duration (h) } & \multirow[b]{2}{*}{ Max. } \\
\hline & & & $\mathrm{SD}$ & Min. & \\
\hline 7820 & 51 & 8.4 & 15.5 & 0.1 & 105.8 \\
\hline 7821 & 52 & 14.1 & 13.2 & 0.1 & 48.3 \\
\hline 7822 & 29 & 4.2 & 10.2 & 0.1 & 51.0 \\
\hline 8250 & 81 & 4.6 & 4.5 & 0.1 & 23.6 \\
\hline 8252 & 28 & 4.6 & 3.8 & 0.1 & 14.1 \\
\hline 9922 & 73 & 3.0 & 6.6 & 0.1 & 50.6 \\
\hline 9923 & 14 & 11.2 & 25.5 & 0.1 & 98.2 \\
\hline 9924 & 71 & 5.7 & 8.0 & 0.1 & 53.7 \\
\hline 9925 & 90 & 3.4 & 3.9 & 0.1 & 20.8 \\
\hline 9926 & 48 & 5.3 & 5.1 & 0.2 & 29.0 \\
\hline 9927 & 29 & 28.6 & 42.5 & 0.1 & 177.1 \\
\hline 10006 & 90 & 3.7 & 11.5 & 0.1 & 109.7 \\
\hline 9930 & 145 & 19.4 & 25.3 & 0.1 & 151.7 \\
\hline 10007 & 84 & 6.0 & 6.2 & 0.1 & 31.5 \\
\hline 10008 & 108 & 7.5 & 6.5 & 0.1 & 36.5 \\
\hline 10009 & 95 & 8.7 & 7.4 & 0.1 & 46.5 \\
\hline 10010 & 123 & 8.1 & 17.7 & 0.1 & 156.3 \\
\hline 10011 & 87 & 13.0 & 9.7 & 0.1 & 47.3 \\
\hline 10012 & 62 & 6.0 & 6.0 & 0.1 & 35.0 \\
\hline 10013 & 60 & 8.5 & 11.0 & 0.1 & 54.3 \\
\hline 10014 & 55 & 8.4 & 14.8 & 0.1 & 94.6 \\
\hline
\end{tabular}

tion of time spent diving consistently occurred at night for sea lions captured in the CAI and eastern Aleutian Islands (EAI) during May 2004.

From a regional perspective, sea lions from the western Aleutian Islands (WAI) spent an average \pm SD of $47.1 \pm 17.9 \%$ of the day on shore, $7.3 \pm 3.4 \%$ diving, and $45.6 \pm 16.9 \%$ at the surface (traveling, resting, or diving to depths $<6 \mathrm{~m}$ ). Sea lions from the CAI spent an average of $57.0 \pm 13.0 \%$ of the day on shore, $13.0 \pm$ $5.4 \%$ diving, and $30.0 \pm 9.0 \%$ at the surface. Sea lions from the EAI spent an average of $64.4 \pm 16.0 \%$ of the day on shore, $8.3 \pm 5.7 \%$ diving, and $27.3 \pm 13.0 \%$ at the surface. Sea lions from the central Gulf of Alaska (CGA) spent an average of $49.9 \pm 22.2 \%$ of the day on shore, $12.3 \pm 8.4 \%$ diving, and $37.8 \pm 15.9 \%$ at the surface.

\section{GLMs}

Predictors of weekly mean and maximum trip durations, and percentage of time spent diving varied among models (Table 5). Foraging effort as indicated by all response variables increased with age for all models (Table 5). Mean trip duration did not differ significantly among regions, whereas maximum trip duration was greatest in the WAI and differed significantly from the CAI (Table 5). Additionally, sea lions from the WAI and the EAI spent less time diving $\mathrm{wk}^{-1}$ 
Table 3. Eumetopias jubatus. Steller sea lion identification (ID), number of days of data (number of records), and summary statistics for activity patterns, including mean \pm SD percentage of time spent diving, at the surface, and hauled out on shore for the duration of the deployment period

\begin{tabular}{|c|c|c|c|c|c|c|c|}
\hline ID & No. of days & Diving & Range & At surface & Range & Hauled out & Range \\
\hline 7820 & 23 & $6.9 \pm 6.9$ & $0.0-28.8$ & $35.9 \pm 23.5$ & $0.3-89.5$ & $57.2 \pm 28.5$ & $0.0-99.7$ \\
\hline 7821 & 34 & $7.8 \pm 4.2$ & $0.0-17.7$ & $51.8 \pm 26.1$ & $6.1-99.2$ & $40.4 \pm 27.6$ & $0.0-93.9$ \\
\hline 7822 & 9 & $4.7 \pm 3.8$ & $0.0-8.9$ & $36.7 \pm 32.7$ & $2.4-91.3$ & $58.6 \pm 35.8$ & $0.0-97.6$ \\
\hline 8250 & 39 & $9.7 \pm 6.8$ & $0.0-23.3$ & $24.8 \pm 15.0$ & $0.0-72.6$ & $65.6 \pm 19.6$ & $11.1-100.0$ \\
\hline 8252 & 15 & $8.2 \pm 7.6$ & $0.0-22.7$ & $20.9 \pm 17.9$ & $0.0-63.6$ & $71.0 \pm 23.5$ & $27.8-100.0$ \\
\hline 9922 & 31 & $3.9 \pm 4.2$ & $0.0-16.4$ & $25.1 \pm 20.9$ & $0.0-99.8$ & $70.9 \pm 23.0$ & $0.0-100.0$ \\
\hline 9923 & 7 & $2.3 \pm 2.7$ & $0.0-5.8$ & $35.5 \pm 31.2$ & $0.0-99.8$ & $62.2 \pm 30.9$ & $0.0-100.0$ \\
\hline 9924 & 49 & $3.4 \pm 3.7$ & $0.0-18.0$ & $21.4 \pm 18.4$ & $0.0-61.4$ & $75.3 \pm 20.8$ & $20.6-100.0$ \\
\hline 9925 & 33 & $4.1 \pm 5.0$ & $0.0-17.2$ & $24.2 \pm 14.7$ & $0.0-54.8$ & $71.7 \pm 17.8$ & $34.6-100.0$ \\
\hline 9926 & 36 & $3.0 \pm 4.1$ & $0.0-16.6$ & $23.6 \pm 18.8$ & $0.0-78.1$ & $73.5 \pm 20.9$ & $5.3-100.0$ \\
\hline 9927 & 48 & $18.7 \pm 12.3$ & $0.0-39.4$ & $41.6 \pm 28.1$ & $0.0-88.9$ & $39.7 \pm 38.3$ & $0.0-100.0$ \\
\hline 10006 & 41 & $1.3 \pm 2.5$ & $0.0-11.3$ & $29.9 \pm 25.3$ & $0.0-99.0$ & $68.8 \pm 26.6$ & $0.0-100.0$ \\
\hline 9930 & 124 & $17.5 \pm 7.9$ & $0.0-39.9$ & $44.9 \pm 23.8$ & $0.0-86.0$ & $37.5 \pm 28.8$ & $0.0-100.0$ \\
\hline 10007 & 56 & $8.6 \pm 7.7$ & $0.0-26.4$ & $21.3 \pm 12.8$ & $0.0-69.1$ & $70.1 \pm 17.7$ & $29.9-100.0$ \\
\hline 10008 & 62 & $12.0 \pm 5.5$ & $0.0-31.4$ & $31.4 \pm 13.5$ & $0.0-59.3$ & $56.6 \pm 17.4$ & $12.2-100.0$ \\
\hline 10009 & 68 & $12.4 \pm 6.2$ & $0.0-27.7$ & $32.4 \pm 16.0$ & $0.0-75.2$ & $55.2 \pm 21.0$ & $0.0-100.0$ \\
\hline 10010 & 61 & $11.5 \pm 7.7$ & $0.0-35.9$ & $31.4 \pm 21.0$ & $0.0-86.6$ & $57.1 \pm 26.5$ & $0.0-100.0$ \\
\hline 10011 & 64 & $19.1 \pm 6.7$ & $0.0-35.9$ & $31.6 \pm 14.4$ & $0.0-63.8$ & $49.3 \pm 19.4$ & $6.3-100.0$ \\
\hline 10012 & 31 & $12.6 \pm 3.0$ & $7.7-22.7$ & $24.9 \pm 12.6$ & $9.8-64.6$ & $62.4 \pm 13.9$ & $25.1-80.9$ \\
\hline 10013 & 34 & $14.3 \pm 7.2$ & $0.0-29.3$ & $28.8 \pm 19.0$ & $1.6-77.8$ & $56.9 \pm 23.9$ & $0.0-98.4$ \\
\hline 10014 & 31 & $11.5 \pm 5.6$ & $2.6-28.8$ & $32.6 \pm 21.3$ & $6.4-83.1$ & $55.9 \pm 25.5$ & $0.0-91.0$ \\
\hline
\end{tabular}

Table 4. Eumetopias jubatus. Mean percentage of time spent diving within 6 periods of the day for 21 juvenile Steller sea lions, as indicated by their identification number (ID). Time of day refers to Greenwich Mean Time (GMT). Overall mean \pm SD are provided for each period

\begin{tabular}{|c|c|c|c|c|c|c|}
\hline ID & $\begin{array}{c}1 \\
(00: 00-3: 59 \mathrm{~h})\end{array}$ & $\begin{array}{c}2 \\
(04: 00-7: 59 \mathrm{~h})\end{array}$ & $\begin{array}{c}3 \\
(08: 00-11: 59 h)\end{array}$ & $\begin{array}{c}4 \\
(12: 00-15: 59 \mathrm{~h})\end{array}$ & $\begin{array}{c}5 \\
(16: 00-19: 59 \mathrm{~h})\end{array}$ & $\begin{array}{c}6 \\
(20: 00-23: 59 \mathrm{~h})\end{array}$ \\
\hline 7820 & 3.4 & 2.6 & 15.2 & 10.9 & 4.2 & 5.3 \\
\hline 7821 & 9.9 & 5.4 & 1.4 & 1.6 & 13.2 & 15.1 \\
\hline 7822 & 5.5 & 1.6 & 7.7 & 9.0 & 1.4 & 3.0 \\
\hline 8250 & 0.2 & 8.1 & 20.1 & 25.9 & 2.5 & 1.2 \\
\hline 8252 & 0.5 & 6.9 & 9.9 & 16.0 & 12.5 & 3.2 \\
\hline 9922 & 1.2 & 6.9 & 3.8 & 6.4 & 3.6 & 1.8 \\
\hline 9923 & 0.4 & 7.9 & 2.7 & 2.2 & 0.7 & 0.0 \\
\hline 9924 & 2.0 & 5.4 & 4.1 & 3.9 & 2.8 & 1.9 \\
\hline 9925 & 2.7 & 1.3 & 1.8 & 4.0 & 6.9 & 4.0 \\
\hline 9926 & 4.0 & 2.0 & 2.7 & 4.1 & 1.7 & 3.2 \\
\hline 9927 & 10.8 & 24.5 & 30.2 & 30.1 & 13.0 & 3.4 \\
\hline 10006 & 1.9 & 1.4 & 0.9 & 1.3 & 1.5 & 1.0 \\
\hline 9930 & 9.1 & 28.3 & 33.9 & 23.1 & 5.6 & 5.3 \\
\hline 10007 & 0.6 & 2.2 & 23.2 & 19.0 & 5.9 & 1.0 \\
\hline 10008 & 0.9 & 2.6 & 34.7 & 26.6 & 4.1 & 3.1 \\
\hline 10009 & 2.0 & 4.7 & 29.5 & 25.4 & 7.9 & 4.8 \\
\hline 10010 & 4.8 & 6.5 & 27.5 & 17.5 & 6.5 & 6.5 \\
\hline 10011 & 4.7 & 5.2 & 44.6 & 38.4 & 14.6 & 7.0 \\
\hline 10012 & 0.0 & 4.0 & 48.5 & 21.8 & 0.9 & 0.5 \\
\hline 10013 & 3.4 & 15.3 & 40.8 & 12.2 & 6.4 & 7.9 \\
\hline 10014 & 4.9 & 7.6 & 37.5 & 10.4 & 4.6 & 3.9 \\
\hline Mean \pm SD & $3.5 \pm 3.2$ & $7.2 \pm 7.2$ & $20.0 \pm 16.2$ & $14.8 \pm 10.8$ & $5.7 \pm 4.3$ & $4.0 \pm 3.4$ \\
\hline
\end{tabular}

than did sea lions from the CAI and presumably the CGA (Table 5). Percentage of time spent diving $\mathrm{wk}^{-1}$ increased with an increase in fractal dimension at both the landscape (mean \pm SD AMFD $=1.097 \pm 0.036$, range $=1.026-1.182$ ) and class (i.e. localized frontal features) scales (mean $\pm \mathrm{SD}, \mathrm{AMFD}=1.059 \pm 0.024$, range $=1.010-1.128$; Table 5). Weekly mean trip durations were inversely related to PD of frontal features $\left(\right.$ mean $\pm \mathrm{SD} P D=0.0035 \pm 0.003$ patches $100 \mathrm{ha}^{-1}$, range $=0.0002-0.0096 ;$ Table 5 ) . 
Table 5. Eumetopias jubatus. Results of 6 stepwise generalized estimating equations used to examine 3 predictor variables (weekly, mean and maximum trip duration, and percentage of time spent diving by 21 juvenile Steller sea lions) with respect to age, region, and metrics (landscape and class) of sea surface temperature heterogeneity. All models were significant. ${ }^{*} p \leq 0.05$. EAI: eastern Aleutian Islands, WAI: western Aleutian Islands, SIDI: Simpson's diversity index, AMFD: area-weighted mean fractal dimension, PD: patch density, PLAND: percentage of landscape, CGA: central Gulf of Alaska

\begin{tabular}{|c|c|c|c|c|c|}
\hline $\begin{array}{l}\text { Response variable } \\
\text { Variables retained }\end{array}$ & $\begin{array}{l}\text { Coefficient } \\
\text { estimate }\end{array}$ & SE & Wald & $\mathrm{p}$ & Model p \\
\hline \multicolumn{6}{|l|}{ Landscape } \\
\hline \multicolumn{6}{|c|}{ Mean trip duration $\mathrm{wk}^{-1}$} \\
\hline Intercept* & 2.510 & 0.112 & 498.484 & 0.000 & \multirow[t]{3}{*}{$4.172 \times 10^{-8}$} \\
\hline Age $^{*}$ & 0.004 & 0.002 & 6.378 & 0.012 & \\
\hline Region (EAI) & -0.214 & 0.121 & 3.136 & 0.077 & \\
\hline \multicolumn{6}{|l|}{ Max. trip duration $w^{-1}$} \\
\hline Intercept & 2.860 & 0.091 & 996.593 & 0.000 & \multirow[t]{3}{*}{$4.649 \times 10^{-10}$} \\
\hline Age $^{*}$ & 0.004 & 0.002 & 5.465 & 0.019 & \\
\hline Region (WAI) ${ }^{*}$ & 0.289 & 0.055 & 27.619 & $1.477 \times 10^{-7}$ & \\
\hline \multicolumn{6}{|l|}{$\%$ time diving $\mathrm{wk}^{-1}$} \\
\hline Intercept $^{*}$ & -32.569 & 19.945 & 2.666 & 0.001 & \multirow{6}{*}{$-61.547 \times 10^{-7}$} \\
\hline Age $^{*}$ & 0.098 & 0.021 & 21.465 & $3.603 \times 10^{-6}$ & \\
\hline Region (EAI)* & -4.194 & 2.157 & 3.782 & 0.052 & \\
\hline Region (WAI) * & -4.223 & 1.648 & 6.568 & 0.010 & \\
\hline SIDI & -6.549 & 3.936 & 2.769 & 0.096 & \\
\hline $\mathrm{AMFD}^{*}$ & 37.819 & 18.315 & 4.264 & 0.039 & \\
\hline \multicolumn{6}{|l|}{ Class } \\
\hline \multicolumn{6}{|c|}{ Mean trip duration $\mathrm{wk}^{-1}$} \\
\hline Intercept* & 2.481 & 0.163 & 231.250 & 0.000 & \multirow[t]{5}{*}{$1.468 \times 10^{-7}$} \\
\hline Age $^{*}$ & 0.004 & 0.002 & 6.067 & 0.014 & \\
\hline Region (EAI) & -0.209 & 0.119 & 3.083 & 0.079 & \\
\hline $\mathrm{PD}^{*}$ & -33.014 & 16.229 & 4.138 & 0.042 & \\
\hline PLAND & 0.006 & 0.004 & 2.984 & 0.084 & \\
\hline \multicolumn{6}{|l|}{ Max. trip duration $w^{-1}$} \\
\hline Intercept* ${ }^{*}$ & 3.028 & 0.114 & 704.327 & 0.000 & \multirow[t]{5}{*}{$2.721 \times 10^{-8}$} \\
\hline Age $^{*}$ & 0.004 & 0.001 & 8.934 & 0.003 & \\
\hline Region (EAI) & -0.161 & 0.102 & 2.491 & 0.114 & \\
\hline Region (WAI) ${ }^{*}$ & 0.196 & 0.055 & 12.920 & 0.000 & \\
\hline $\mathrm{PD}$ & -21.547 & 11.220 & 3.688 & 0.055 & \\
\hline \multicolumn{6}{|l|}{$\%$ time diving $\mathrm{wk}^{-1}$} \\
\hline Intercept & -24.666 & 16.752 & 2.168 & 0.141 & \multirow{6}{*}{$4.864 \times 10^{-7}$} \\
\hline $\operatorname{Age}^{*}$ & 0.110 & 0.021 & 28.274 & $1.053 \times 10^{-7}$ & \\
\hline Region (CGA) & -3.486 & 2.303 & 2.292 & 0.130 & \\
\hline Region (EAI) ${ }^{*}$ & -5.712 & 2.090 & 7.472 & 0.006 & \\
\hline Region (WAI) ${ }^{*}$ & -5.510 & 1.763 & 9.768 & 0.002 & \\
\hline $\mathrm{AMFD}^{*}$ & 30.284 & 15.732 & 3.706 & 0.054 & \\
\hline
\end{tabular}

mond et al. 2005, 2006), enabling sea lions to remain at sea for longer periods of time. Summary statistics of activity patterns were also similar to findings of other researchers who found that on average, Steller sea lions spent $44 \%$ of their time at sea (Rehberg 2005, Call et al. 2007). Our results also corroborated other studies (Loughlin et al. 2003, Fadely et al. 2005, Call et al. 2007) indicating that most diving activity of pups and juveniles occurred during the night when sea lions may have been foraging on shallow vertically migrating prey such as walleye pollock Theragra chalcogramma. Pollock tend to school at depth during daytime hours and disperse as they rise in the water column at night (Sinclair et al. 1994). These results imply that sea lions spent the remainder of time at sea conducting other activities (unless foraging activities occurred within $6 \mathrm{~m}$ of the surface).

Sea lions from the WAI spent less time diving while at sea, yet maximum trip durations were greatest for this group of animals. These results coupled with the proportion of time spent at the surface possibly indicate that more time was allocated to traveling and less to resource utilization. Relative to the other 2 regions, sea lions from the EAI also spent less time diving during the week, but their diving behavior constituted a greater proportion of their overall time at sea (Table 3). Assuming that foraging indices are indicators of variability in marine resources (Boyd 1999) and reflect differences in the cost of prey acquisition (Costa et al. 1989, Merrick

\section{DISCUSSION}

Similar to other studies of otariids (McCafferty et al. 1998, Baker \& Donohue 2000, Baylis et al. 2005), including Steller sea lions (Raum-Suryan et al. 2004, Fadely et al. 2005, Pitcher et al. 2005, Call et al. 2007, Rehberg \& Burns 2008), age was a significant factor for predicting the amount of time spent at sea and diving. These results were not surprising, as an increase in experience coupled with the development of physiological abilities (muscle and blood oxygen stores and thermal tolerance) occur with age and growth (Rich-
\& Loughlin 1997), these data suggest that sea lions from the EAI were either more efficient foragers than those from the WAI or resources were more attainable in the EAI than the WAI. Results of Lander et al. (2009), which indicated that diet diversity and habitat diversity were greater for the EAI than the WAI, support the latter notion if in fact diet and habitat diversity reflect prey diversity and abundance in the environment. Results should be interpreted with caution, however, because regional differences in diving effort may have been hampered by foraging behavior, age, season, or interaction effects (which were not examined due to 
lack of degrees of freedom). Various foraging tactics are used by Steller sea lions to feed on different types of prey as a result of differences in prey characteristics such as size, age, and behavior. Because dominant prey types vary among regions (Sinclair \& Zeppelin 2002, Lander et al. 2009), it is possible that foraging effort among regions was influenced by different strategies used for the pursuit, capture, and consumption of disparate prey. Furthermore, sample sizes were limited and all age classes of sea lions were not equally represented among regions. The weaning status of sea lions captured for this study was unknown, and individuals that were still nursing may have influenced our interpretation of the results if they were less motivated to find food resources affected by environmental heterogeneity (McIntyre \& Wiens 1999). Unfortunately, lack of long-term data for most animals prevented us from examining how these behaviors changed over longer periods of time.

Other studies have indicated that the amount and spatial arrangement of resources and habitat constrain the location, movement, and foraging dynamics of other species (Crist et al. 1992, Ferguson et al. 1998, With et al. 1999). Our results indicated that diving activity of Steller sea lions increased as the shape complexity of localized frontal features within the study areas increased, whereas average weekly trip duration was inversely related to PD of those features. Assuming that increases in foraging effort and trip durations are predicted if prey availability is reduced (Trillmich \& Ono 1991, Lunn et al. 1993, Hood \& Ono 1997, Merrick \& Loughlin 1997, McCafferty et al. 1998, Georges et al. 2000, Melin 2002, Weimerskirch et al. 2003), this combination of results suggests that sea lions had a more difficult time obtaining resources as the structure of SST frontal features became more complex, but may have attained resources more quickly as the number of patches comprising frontal features increased. Thus, aggregated, dense frontal features were probably conducive to foraging effort as opposed to time periods when these features were forming or dissipating. The lack of significance for AMCA and PLAND further suggests that complexity, rather than size, of frontal features influenced diving behavior.

Frontal zones, including thermal fronts, tend to be regions of enhanced primary productivity relative to surrounding areas (Graham et al. 2001, Okkonen et al. 2003, Bradshaw et al. 2004) and are important to other marine mammals (Hindell et al. 1991, Sinclair et al. 1994, Moore et al. 2002, Etnoyer et al. 2006, DoniolValcroze et al. 2007), seabirds (Hunt et al. 1999), sea turtles (Etnoyer et al. 2006), pelagic fishes (Royer et al. 2004), and other marine fauna (Graham et al. 2001). These predators likely concentrate at fronts due to food availability or thermal constraints, which may be evo- lutionary, ecological, or physiological (Brandt 1993). For example, metabolic rates and gut passage rates of some fish species are affected by water temperature (Gillooly et al. 2001). It is also believed that water temperature influences the availability, behavior, spawning, and survival of forage fish (Bailey et al. 1995), which are important prey species of Steller sea lions. Additionally, frontal features may be beneficial because they have more thermal habitats per unit area than surrounding waters and have a greater probability of encompassing a preferred range of temperature (Brandt et al. 1980), thereby meeting energetic demands and other requirements needed for survival.

Unlike diving activity, trip duration did not increase as fractal dimension of frontal features increased, despite the idea that the 2 variables generally coincide or that it may take longer to navigate around irregular patches. However, assuming frontal features at the scales examined were used by Steller sea lions, other factors such as permeability of features, proximity among features, or location of features relative to haulouts or rookeries may have affected the results. For example, the spatial arrangement and shape of features presumably reflect their connectivity, but not necessarily their boundary characteristics. Although diving activity appeared to be more efficient during times when study areas contained connected, aggregated features, the configuration of features may not have affected trip durations if the features themselves did not pose a barrier to sea lions. Additionally, if sea lions tend to target frontal features of a specific configuration, which may be indicative of the strength of an underlying process or the concentration of a prey field, then trip durations may not have been related to measures of AMFD or the amount of diving activity because those features can potentially occur anywhere within a given study area mosaic.

In contrast to results reported by Lander et al. (2009), which indicated that regional patterns of SST diversity were fairly consistent with regional population trajectories of Steller sea lions, indices of foraging effort examined for this study were not related to SST diversity. Although this was unexpected, our results and those of Lander et al. (2009) appear to conform to the theory that landscape composition (e.g. habitat diversity) has large, direct effects on population dynamics and persistence (possibly through direct effects on reproduction and mortality), whereas landscape configuration (e.g. fractal dimension) affects population dynamics indirectly through its effects on amongpatch movements (Fahrig \& Nuttle 2003). Although an interesting observation, additional empirical evidence is needed to assess this hypothesis, which differs slightly from classical metapopulation theory, an approach that predicts that survival of endangered 
populations is dominated by stochastic events and the spatial arrangement of suitable habitat (Hanski 1998).

The National Marine Fisheries Service (NMFS) Recovery Plan for Steller sea lions (NMFS 2008) suggests that critical habitat should be enhanced to incorporate the spatial and temporal variation of essential oceanographic features that potentially influence the distribution and abundance of prey and ultimate conservation of Steller sea lions. It is therefore necessary to determine which features constitute essential habitat, how those features persist over time, and how sea lions (and their prey) exploit those features. For this study, we described how the foraging effort of Steller sea lions was related to the heterogeneity of smallscale surface temperature gradients. However, we have an incomplete understanding of how exactly those features were truly perceived or used by sea lions because the distributions of sea lion locations (or dives) were not analyzed with respect to the exact locality of defined features due to the spatial resolution of the telemetry and remote sensing data. Furthermore, the environmental patterns demarcated for this exercise may have been sensitive to changes in scale and decision rules used to classify the data (e.g. patch definitions and parameter inputs; Turner et al. 1989). Similar studies in the future will undoubtedly benefit from simultaneously sampling the prey environment, the sophistication of ocean observing satellites, and the advancement of GPS technology.

Linking underlying processes to observed environmental patterns is essential for understanding the functional relevance of our results. Tidal advection, weather conditions, wind-forcing, and bottom topography can all contribute to the formation of frontal features and create patterned heterogeneity in the marine environment. At larger meso-scales, these gradients and/or fronts can represent the boundaries between different water masses or they may be indicative of other mesoscale features such as transient eddies (Ladd et al. 2005). It has been suggested that northern fur seals Callorhinus ursinus, and possibly Steller sea lions on longer pelagic excursions, are attracted to these features (Sinclair et al. 1994, Fadely et al. 2005, Ream et al. 2005), which likely concentrate productivity and prey, facilitate movement, and increase foraging opportunities (Ream et al. 2005). At smaller spatial scales, such as headlands and islands where Steller sea lions tend to congregate more often, currents may interact with topography to produce complex 3-dimensional secondary flows that result in physical and biological fronts that can influence the distribution of many organisms (Wolanski \& Hamner 1988). Other 2-dimensional horizontal features such as coastal fronts are also associated with vertical motion and heterogeneity (Abbott 1993) and may be surface expressions of greater subsurface gradients (Roughan et al. 2005). Although there were cases when plotted temperature profiles within or near the border of classified features supported this idea, the majority of temperature profiles collected during this study indicated that sea lions were foraging within the mixed layer. Hence, small-scale surface gradients, which typically result from surface wind stress (Langmuir circulation) or internal tides and are often marked by an entrainment of surface debris, buoyant particulates, and plankton (Wolanski \& Hamner 1988, The Open University 2001), should be investigated further. Thin layers, which occur in coastal areas, contain high concentrations of living organisms, and possibly result from similar processes (Franks 1995, Johnston et al. 2009), also warrant future attention.

Typing small-scale features used by juvenile Steller sea lions inevitably will entail the use of additional sensors to collect precise in situ measurements of oceanographic variables in coastal waters unavailable to satellite remote sensing platforms. Recent advances in biologging instruments, including the development of a conductivity-temperature-depth SRDL (CTDSRDL), are promising and have allowed examination of the behaviors of larger marine mammals in the context of a 3-dimensional environment (Biuw et al. 2007), mapping major fronts (Charrassin et al. 2008), and analyzing data in innovative ways (Weise et al. in press).

Acknowledgements. We thank the entire staff of the Alaska Ecosystems Program at the National Marine Mammal Laboratory, Alaska Fisheries Science Center, NOAA Fisheries, the Alaska Department of Fish and Game, and the crews of the MV 'Pacific Star,' MV 'Tiglax,' and MV 'Woldstad' for all of their support and assistance in capturing and instrumenting sea lions. J. Benson, L. Delwiche, A. Greig, D. Johnson, A. Zerbini, the University of Washington (UW) Biostatistics consulting group, and the University of St. Andrew's Sea Mammal Research Unit also provided valuable assistance with data processing and analysis. This manuscript was greatly improved through reviews by J. Ver Hoeuf, W. Testa, G. Duker, J. Lee, and 3 anonymous reviewers. This work was conducted under Federal Marine Mammal Permit no. 7821532 and UW IACUC protocol no. 2887-09. The use of trade, product, or firm names in this publication is for descriptive purposes only and does not imply endorsement by the US Government.

\section{LITERATURE CITED}

Abbott MR (1993) Phytoplankton patchiness: ecological implications and observation methods. In: Levin SA, Powell TM, Steele JH (eds) Patch dynamics. Springer-Verlag, New York, p 37-49

Argos (1996) User's manual, satellite based data collection and location system. Service Argos, Landover, MD

Atkinson S, DeMaster DP, Calkins DG (2008) Anthropogenic causes of the western Steller sea lion Eumetopias jubatus population decline and their threat to recovery. Mammal Rev 38:1-18 
Bailey KM, Macklin SA, Reed RK, Brodeur RD and others (1995) ENSO events in the northern Gulf of Alaska, and effects on selected marine fisheries. Calif Coop Ocean Fish Invest Rep 36:78-96

Baker JD, Donohue MJ (2000) Ontogeny of swimming and diving in northern fur seal (Callorhinus ursinus) pups. Can J Zool 78:100-109

Baylis AMM, Page B, Peters K, McIntosh R, Mckenzie J, Goldsworthy $\mathrm{S}$ (2005) The ontogeny of diving behaviour in New Zealand fur seal pups (Arctocephalus forsteri). Can J Zool 83:1149-1161

Benson AJ, Trites AW (2002) Ecological effects of regime shifts in the Bering Sea and eastern North Pacific Ocean. Fish Fish 3:95-113

Biuw M, Boehme L, Guinet C, Hindell M and others (2007) Variations in behavior and condition of a Southern Ocean top predator in relation to in situ oceanographic conditions. Proc Natl Acad Sci USA 104:13705-13710

Boyd IL (1999) Foraging and provisioning in Antarctic fur seals: interannual variability in time-energy budgets. Behav Ecol 10:198-208

Boyd IL, Hawker EJ, Brandon MA, Staniland IJ (2001) Measurement of ocean temperatures using instruments carried by Antarctic fur seals. J Mar Syst 27:277-288

$>$ Bradshaw CJA, Higgins J, Michael KJ, Wotherspoon SJ, Hindell MA (2004) At-sea distribution of female elephant seals relative to variation in ocean surface properties. ICES J Mar Sci 61:1014-1027

Braham HW, Everitt RD, Rugh DJ (1980) Northern sea lion population decline in the eastern Aleutian Islands. J Wildl Manag 44:25-33

Brandt SB (1993) The effect of thermal fronts on fish growth: a bioenergetics evaluation of food and temperature. Estuaries 16:142-159

Brandt SB, Magnuson JJ, Crowder LB (1980) Thermal habitat partitioning of fishes in Lake Michigan. Can J Fish Aquat Sci 37:1557-1564

Cadenasso ML, Pickett STA, Weathers KC, Jones CG (2003) A framework for a theory of ecological boundaries. Bioscience 53:750-758

> Call KA, Loughlin TR (2005) An ecological classification of Alaskan Steller sea lion (Eumetopias jubatus) rookeries: a tool for conservation/management. Fish Oceanogr 14 (Suppl 1):212-222

Call KA, Fadely BS, Greig A, Rehberg MJ (2007) At-sea and on-shore cycles of juvenile Steller sea lions (Eumetopias jubatus) derived from satellite dive recorders: a comparison between declining and increasing populations. DeepSea Res II 54:298-310

Campbell JW, Blaisdell JM, Darzi M (1995) Level-3 SeaWiFS data products: spatial and temporal binning algorithms. In: Hooker SB, Firestone ER, Acker JG (eds) NASA Tech Memo 104566, Vol 32. NASA Goddard Space Flight Center, Greenbelt, MD

> Charrassin JB, Hindell M, Rintoul SR, Roquet F and others (2008) Southern Ocean frontal structure and sea-ice formation rates revealed by elephant seals. Proc Natl Acad Sci USA 105:11634-11639

Costa DP, Croxall JP, Duck C (1989) Foraging energetics of Antarctic fur seals in relation to changes in prey availability. Ecology 70:596-606

Crist TO, Guertin DS, Wiens JA, Milne BT (1992) Animal movement in heterogeneous landscapes: an experiment with Eleodes beetles in shortgrass prairie. Funct Ecol 6:536-544

DeMaster D, Atkinson S (2002) Steller sea lion decline: Is it food? II. University of Alaska Sea Grant, AK-SG-0202, Fairbanks, AK
Doniol-Valcroze T, Berteaux D, Larouche P, Sears R (2007) Influence of thermal fronts on habitat selection by four rorqual whale species in the Gulf of St. Lawrence. Mar Ecol Prog Ser 335:207-216

Etnoyer P, Canny D, Mate BR, Morgan LE, Ortega-Ortiz JG, Nichols WJ (2006) Sea-surface temperature gradients across blue whale and sea turtle foraging trajectories off the Baja California Peninsula, Mexico. Deep-Sea Res II 53: 340-358

Fadely BS, Robson BW, Sterling JT, Greig A, Call KA (2005) Immature Steller sea lion (Eumetopias jubatus) dive activity in relation to habitat features of the eastern Aleutian Islands. Fish Oceanogr 14:243-258

Fahrig L, Nuttle WK (2003) Population ecology in spatially heterogeneous environments. In: Lovett GM, Jones CG, Turner MG, Weathers KC (eds) Ecosystem function in heterogeneous landscapes. Springer Science + Business Media, New York, p 95-118

Fedak MA, Lovell P, McConnell BJ (1996) MAMVIS: A marine mammal behaviour visualization system. J Visual Comput Animation 7:141-147

Fedak MA, Lovell P, McConnell B, Hunter C (2002) Overcoming the constraints of long range radio telemetry from animals: getting more useful data from smaller packages. Integr Comp Biol 42:3-10

Ferguson SH, Taylor MK, Born EW, Messier F (1998) Fractals, sea-ice landscape and spatial patterns of polar bears. J Biogeogr 25:1081-1092

Forman RT, Godron M (1986) Landscape ecology. Wiley Publishers, New York

- Franks PJS (1995) Thin layers of phytoplankton: a model of formation by near-inertial wave shear. Deep-Sea Res I 42: 75-91

Fritz LW, Hinckley S (2005) A critical review of the regime shift - 'junk food' - nutritional stress hypothesis for the decline of the western stock of Steller sea lion. Mar Mamm Sci 21:476-518

Fritz L, Lynn M, Kunisch E, Sweeney K (2008) Aerial, ship, and land-based surveys of Steller sea lions (Eumetopias jubatus) in Alaska, June and July 2005 and 2007. US Dept Comm, NOAA Tech Memo NMFS-AFSC-183

Gende SM, Sigler MF (2006) Persistence of forage fish 'hot spots' and its association with foraging Steller sea lions (Eumetopias jubatus) in southeast Alaska. Deep-Sea Res II 53:432-441

Georges JY, Bonadonna F, Guinet C (2000) Foraging habitat and diving activity of lactating Subantarctic fur seals in relation to sea surface temperature at Amsterdam Island. Mar Ecol Prog Ser 196:291-304

Gillooly JF, Brown JH, West GB, Savage VM, Charnov EL (2001) Effects of size and temperature on metabolic rates. Science 293:2248-2251

Graham WM, Pages F, Hamner WM (2001) A physical context for gelatinous zooplankton aggregations: a review. Hydrobiologia 451:199-212

Gustafson EJ (1998) Quantifying landscape spatial pattern: What is the state of the art? Ecosystems 1:143-156

Halekoh U, Højsgaard S, Yan J (2006) The R package geepack for generalized estimating equations. J Stat Software 15:1-11

Hanski I (1998) Metapopulation dynamics. Nature 396:41-49

Hargis CD, Bisonette JA, David JL (1997) Understanding measures of landscape pattern. In: Bissonette JA (ed) Wildlife and landscape ecology: effects of pattern and scales. Springer-Verlag, New York, p 231-261

Heath RB, DeLong R, Jameson V, Bradley D, Spraker T (1997) Isoflurane anesthesia in free ranging sea lion pups. J Wildl Dis 33:206-210 
Hindell MA, Burton HR, Slip DJ (1991) Foraging areas of southern elephant seals, Mirounga leonia, as inferred from water temperature data. Aust J Mar Freshw Res 42: $115-128$

Holmes EE, York AE (2003) Using age structure to detect impacts on threatened populations: a case study with Steller sea lions. Conserv Biol 17:1794-1806

Holmes EE, Fritz LW, York AE, Sweeney K (2007) Age-structure modeling reveals long-term decline in the natality of western Steller sea lions. Ecol Appl 17:2214-2232

Hood WR, Ono KA (1997) Variation in maternal attendance patterns and pup behavior in a declining population of Steller sea lions (Eumetopias jubatus). Can J Zool 75:1241-1246

Hunt GL Jr, Mehlum F, Russell RW, Irons D, Decker MB, Becker PH (1999) Physical processes, prey abundance, and the foraging ecology of seabirds. In: Adams NJ, Slotow RH (eds) Proc 22nd Int Ornithol Cong, Durban. BirdLife South Africa, Johannesburg, p 2040-2056

Johnston TMS, Cheriton OM, Pennington JT, Chavez FP (2009) Thin phytoplankton layer formation at eddies, filaments, and fronts in a coastal upwelling zone. Deep-Sea Res II 56:246-259

King JT, Gelatt TS, Pitcher KW, Pendleton GW (2007) A fieldbased method for estimating age in free-ranging Steller sea lions (Eumetopias jubatus) less than twenty-four months of age. Mar Mamm Sci 23:262-271

Ladd C, Jahncke J, Hunt GL, Coyle KO, Stabeno PJ (2005) Hydrographic features and seabird foraging in Aleutian Passes. Fish Oceanogr 14 (Suppl 1):178-195

Lander ME, Loughlin TR, Logsdon MG, VanBlaricom GR, Fadely BS, Fritz LW (2009) Regional differences in the spatial and temporal heterogeneity of oceanographic habitat used by Steller sea lions. Ecol Appl 19:1645-1659

Liang KY, Zeger S (1986) Longitudinal data analysis using generalized linear models. Biometrika 73:13-22

Loughlin TR (1998) The Steller sea lion: a declining species. Biosphere Conserv 1:91-98

Loughlin TR, York AE (2000) An accounting of the sources of Steller sea lion, Eumetopias jubatus, mortality. Mar Fish Rev 62:40-45

Loughlin TR, Sterling JT, Merrick R, Sease JL, York AE (2003) Diving behavior of immature Steller sea lions (Eumetopias jubatus). Fish Bull 101:566-582

Lovett GM, Jones CG, Turner MG, Weathers KC (2003) Ecosystem function in heterogeneous landscapes. In: Lovett GM, Jones CG, Turner MG, Weathers KC (eds) Ecosystem function in heterogeneous landscapes. Springer Science + Business Media, New York, p 1-4

Lunn NJ, Boyd IL, Barton T, Croxall JP (1993) Factors affecting the growth rate and mass at weaning of Antarctic fur seals at Bird Island, South Georgia. J Mammal 74:908-919

McAllister DC, Calkins DG, Pitcher KW (2001) Underwater capture of juvenile Steller sea lions with scuba: a narrated video presentation. In: Jewett SC (ed) Cold water diving for science. Alaska Sea Grant College Program, University of Alaska Fairbanks, AK-SG-01-06, p 53-56

> McCafferty DJ, Boyd IL, Taylor RI (1998) Diving behaviour of Antarctic fur seal (Arctocephalus gazella) pups. Can J Zool 76:513-520

McConnell BJ, Chambers C, Fedak MA (1992) Foraging ecology of southern elephant seals in relation to the bathymetry and productivity of the Southern Ocean. Antarct Sci 4:393-398

McGarigal K, Marks BJ (1995) FRAGSTATS: spatial pattern analysis program for quantifying landscape structure. Gen Tech Rep PNW-GTR-351, USDA Forest Service, Pacific Northwest Research Station, Portland, OR
McGarigal K, Cushman SA, Neel MC, Ene E (2002) FRAGSTATS: spatial pattern analysis program for categorical maps. Available at www.umass.edu/landeco/ research/fragstats/fragstats.html

McIntyre NE, Wiens JA (1999) Interactions between landscape structure and animal behavior: the roles of heterogeneously distributed resources and food deprivation on movement patterns. Landscape Ecol 14:437-447

Melin SR (2002) The foraging ecology and reproduction of the California sea lion (Zalophus californianus californianus). $\mathrm{PhD}$ dissertation, University of Minnesota, St Paul, MN

Merrick RL (1995) The relationship of the foraging ecology of Steller sea lions (Eumetopias jubatus) to their population decline in Alaska. PhD dissertation, University of Washington, Seattle, WA

> Merrick RL, Loughlin TR (1997) Foraging behavior of adult female and young-of-the-year Steller sea lions in Alaskan waters. Can J Zool 75:776-786

Moore SE, Watkins WA, Daher MA, Davies JR, Dahlheim ME (2002) Blue whale habitat associations in the northwest Pacific: analysis of remotely-sensed data using a geographic information system. Oceanography 15:20-25

NMFS (National Marine Fisheries Service) (2008) Recovery plan for the Steller sea lion, eastern and western distinct population segments of Steller sea lion (Eumetopias jubatus). NMFS, National Oceanic and Atmospheric Administration, Silver Spring, MD

Okkonen SR, Weingartner TJ, Danielson SL, Musgrave DL, Schmidt GM (2003) Satellite and hydrographic observations of eddy-induced shelf-slope exchange in northwestern Gulf of Alaska. J Geophys Res 108:3033, doi:10.1029/ 2002JC001342

Pascual MA, Adkinson MD (1994) The decline of the Steller sea lion in the Northeast Pacific: demography, harvest or environment? Ecol Appl 4:393-403

Pitcher KW, Rehberg MJ, Pendleton GW, Raum-Suryan KL, Gelatt TS, Swain UG, Sigler MF (2005) Ontogeny of dive performance in pup and juvenile Steller sea lions in Alaska. Can J Zool 83:1214-1231

> Raum-Suryan KL, Rehberg MJ, Pendleton GW, Pitcher KW, Gelatt TS (2004) Development of dispersal, movement patterns, and haul-out use by pup and juvenile Steller sea lions (Eumetopias jubatus) in Alaska. Mar Mamm Sci 20: $823-850$

Ream RR, Sterling JT, Loughlin TR (2005) Oceanographic features related to northern fur seal migratory movements. Deep-Sea Res II 52:823-843

Rehberg MJ (2005) Pattern matters: changes in the organization of swimming and diving behavior by Steller sea lion juveniles in coastal Alaska waters. MS thesis, University of Alaska, Anchorage, AK

> Rehberg MJ, Burns JM (2008) Differences in diving and swimming behavior of pup and juvenile Steller sea lions (Eumetopias jubatus) in Alaska. Can J Zool 86:539-553

> Richmond JP, Burns JM, Rea LD, Mashburn KL (2005) Postnatal ontogeny of erythropoietin and hematology in freeranging Steller sea lions (Eumetopias jubatus). Gen Comp Endocrinol 141:240-247

> Richmond JP, Burns JM, Rea LD (2006) Ontogeny of total body oxygen stores and aerobic dive potential in Steller sea lions (Eumetopias jubatus). J Comp Physiol B 176: 535-545

> Roughan M, Mace AJ, Largier JL, Morgan SG, Fisher JL, Carter ML (2005) Subsurface recirculation and larval retention in the lee of a small headland: a variation on the upwelling shadow theme. J Geophys Res 110:C10027, doi: 10.1029/2005JC002898 
Royer F, Fromentin JM, Gaspar P (2004) Association between bluefin tuna schools and oceanic features in the western Mediterranean. Mar Ecol Prog Ser 269:249-263

Sinclair EH, Zeppelin TK (2002) Seasonal and spatial differences in diet in the western stock of Steller sea lions. J Mammal 83:973-990

Sinclair E, Loughlin TR, Pearcy W (1994) Prey selection by northern fur seals (Callorhinus ursinus) in the eastern Bering Sea. Fish Bull 92:144-156

The Open University (2001) Ocean circulation, 2nd edn. Butterworth-Heinemann, Oxford

Trillmich F, Ono KA (1991) Pinnipeds and El Niño: responses to environmental stress. Springer-Verlag, New York

> Trites AW, Miller AJ, Maschner HDG, Alexander MA and others (2007) Bottom-up forcing and the decline of Steller sea lions (Eumetopias jubatus) in Alaska: assessing the ocean climate hypothesis. Fish Oceanogr 16:46-67

Turner MG, O'Neill RV, Gardner RH, Milne BT (1989) Effects of changing spatial scale on the analysis of landscape pattern. Landscape Ecol 3:153-162

Turner MG, Gardner RH, O'Neill RV (2001) Landscape ecology in theory and practice; pattern and process. SpringerVerlag, New York

Weimerskirch H, Inchausti P, Guinet C, Barbraud C (2003) Trends in bird and seal populations as indicators of a system shift in the Southern Ocean. Antarct Sci 15:249-256

Weise MJ, Harvey JT, Costa DP (in press) The role of body size in individual-based foraging strategies of a top marine predator. Ecology

Editorial responsibility: Daniel Costa,

Santa Cruz, California, USA
White EP, Brown JH (2003) The template: patterns and processes of spatial variation. In: Lovett GM, Jones CG, Turner MG, Weathers KC (eds) Ecosystem function in heterogeneous landscapes. Springer Science + Business Media, New York, p 31-47

Wiens JA (1989) Spatial scaling in ecology. Funct Ecol 3: 385-397

Wiens JA (2002) Riverine landscapes: taking landscape ecology into the water. Freshw Biol 47:501-515

With KA, Cadaret SJ, Davis C (1999) Movement responses to patch structure in experimental fractal landscapes. Ecology 80:1340-1353

> Wolanski E, Hamner WM (1988) Topographically controlled fronts in the ocean and their biological influence. Science 241:177-181

> Womble JN, Sigler MF (2006) Seasonal availability of abundant, energy-rich prey influences the abundance and diet of a marine predator, the Steller sea lion Eumetopias jubatus. Mar Ecol Prog Ser 325:281-293

> Yan J, Fine J (2004) Estimating equations for association structures. Stat Med 23:859-874

York A (1994) The population decline of northern sea lions, 1975-1985. Mar Mamm Sci 10:38-51

York AE, Merrick RL, Loughlin TR (1996) An analysis of the Steller sea lion metapopulation in Alaska. In: McCullough DR (ed) Metapopulations and wildlife conservation. Island Press, Washington, DC, p 259-292

Zeger SL, Liang KY (1986) Longitudinal data analysis for discrete and continuous outcomes. Biometrics 42:121-130

Submitted: March 30, 2009; Accepted: November 26, 2009

Proofs received from author(s): February 3, 2010 